\title{
Effect of Vitamin C Pre-treatment on Germination, Seedling Growth and some Metabolic Activities of kidney bean (Phaseolus vulgaris $\mathrm{L}$ ) under Different Temperatures.
}

\author{
Hanan. M. Abou El-Ghit \\ Department of Botany and Microbiology, Faculty of Science, \\ University of Helwan, Cairo, Egypt.
}

\begin{abstract}
VITAMIN C pretreatments showed pronounced mitigating effects on kidney bean under different temperatures, where the germination \%, seedling gr owth and vigor were significantly increased, compared with the corresponding results obtained under exposure to different temperatures without vitamin $\mathrm{C}$ pretreatments. A similar trend was shown with regard to total chlorophyll, total carbohy drate and soluble protein contents. Lower temperatures as well as vitamin $\mathrm{C}$ pretreatments led to higher accumulation of soluble sugar contents in seedlings. Proline content was considerably increased by lower temperature levels and vitamin $\mathrm{C}$ pretreatments also enhanced its increase. Vitamin $\mathrm{C}$ was assumed to act synergistically with lower temperatures in decreasing proline dehydrogenase level. The activity levels of some hydrolytic enzymes and antioxidant enzymes were affected by both lower temperatures and vitamin $\mathrm{C}$ treatments. Thus, amylase and protease activities were significantly increased by lower temperatures and vitamin $\mathrm{C}$ pretreatments. Catalase and ascorbate peroxidase activities were remarkably elevated by decreasing temperature but were decreased as a result of vitamin $\mathrm{C}$ pretreatments. Higher vitamin $\mathrm{C}$ levels were more effective in alleviating the adverse effects of lower temperature on the above mentioned criteria of the kidney bean.
\end{abstract}

Keywords: Kidney bean, Germination, Temperature, Chlorophyll, Proline, Antioxidant enzymes, Hy droly tic enzy mes.

Kidney bean (Phaseolus vulgaris L) is a herbaceous annual plant grown worldwide for its edible dry seeds or unripe fruits. Its leaf is also occasionally used as a vegetable and the straw as a fodder. As a member of the legume family Fabaceae, its dry seeds are high in starch, protein and dietary fibers. The seeds also represent an excellent source of iron, potassium, selenium, molybdenum, thiamine, vitamin $\mathrm{B}_{6}$ and folate. It is a low temperature sensitive plant where the lowest safe temperature for bean is $7^{\circ} \mathrm{C}$; after which injury symptoms appear (Zeinolabedin et al., 2013). 
Germination seems to be highly dependent on environment (Kurt, 2010). Temperature is an environmental factor which affects germination ability of plants (Carter et al., 2003). Optimum seed germination and seedling emergence of many plants occur at relatively high temperatures $\left(25-30^{\circ} \mathrm{C}\right)$ such as bean, tomato, eggplant, watermelon, cucumber, and melon (Tzortzakis, 2009). Germination and seedling growth of some species of Pisum sativum grown under low temperature conditions were very slow, compared to those at room temperature (Shereena and Salim, 2006). Maximum percentage of germination of Solanum nigrum was observed at $27^{\circ} \mathrm{C}$ while the lowest percentage of seed germination was observed at low temperature (Suthar et al., 2009). Low temperature is a serious problem during germination and early seedling growth and the major cause of uneven emergence and poor stand establishment. The lifetime of reactive oxygen species (ROS) caused by stresses is determined by the antioxidative system which comprises numerous enzymes and compounds of low molecular weights (Ya-jing Guan and Jin Hu, 2009). ROS interact with DNA, proteins, lipids and pigments causing huge cellular damage. In this connection, accumulation of $\mathrm{H}_{2} \mathrm{O}_{2}$ causes oxidation of cellular targets such as DNA, proteins, and lipids leading to mutagenesis and cell death (Raven, 2000). Catalase and ascorbate peroxidases detoxify peroxides such as $\mathrm{H}_{2} \mathrm{O}_{2}$.

Vitamins are growth factors that act as coenzymes for numerous metabolic enzymes. Vitamin C plays multiple roles in plant growth, cell division functioning, cell wall expansion and other developmental processes (Behairy et al., 2012).

Thus, the present work intended to determine the effects of vitamin $\mathrm{C}$ pretreatments on seed germination, seedling development and some metabolic activities of kidney bean under different temperatures.

\section{Material and Methods}

Kidney bean seeds (Phaseolus vulgaris L, var. Navy) were obtained from the Agriculture Research Center, Ministry of Agriculture, Giza, Egypt. The experiment was arranged in a randomized split-plot design with four replicates. Seeds were carefully selected and surface sterilized in $1 \%$ sodium hypochlorite solution for $2 \mathrm{~min}$. and then thoroughly rinsed with sterile water in order to remove any contaminant that might still adhere to the seed surface. The sterilized seeds of kidney bean were then quickly air dried and divided into two groups; one group was soaked in water $24 \mathrm{hr}$, while the other was divided into three subgroups and soaked for $24 \mathrm{hr}$ in vitamin $\mathrm{C}$ at three different concentrations; 25, 50 and $100 \mathrm{ppm}$ under dark conditions. Germination and growth were carried out in growth chambers at 30, 18, $15,10,8$ and $5^{\circ} \mathrm{C}$ according to The Real Seed Catalogue; 8 hrs dark and 16 hrs light. Seed germination was observed daily with fresh water solution added to the Petri dishes as necessary to maintain moisture levels. Measurements of seed ling growth and metabolic activities were made on seedlings 15 days old. Seedling vigor index was estimated by the multiplying seedling length in $\mathrm{cm}$ by germination percentage (ISTA, 1999). Dry weights were determined after drying the plant tis sue to a constant weight in an oven at $85^{\circ} \mathrm{C}$ for $12 \mathrm{hr}$. Metabolic activities within seedlings were Egypt. J. Bot., 56, No. 2 (2016) 
determined by measuring total chlorophylls $(a+b)$, total carbohydrates, soluble sugars, protein and proline contents and activities of amylase, protease, catalase, ascorbate peroxidase and proline dehydrogenase. Total chlorophylls of the seedlings were measured using the method described by Metzner et al. (1965). Soluble sugars and total carbohydrate content were determined using the anthrone method described by Umbriet et al. (1959). Soluble proteins content of leaf samples was determined using the method of Lowry et al. (1951). Free proline content of the plant tis sue was determined according to the method described by Bates et al. (1973). Enzymes were extracted and their activities assayed according to Bergmeyer (1974).

\section{Results}

Effect of vitamin $C$ and different temperatures on seed germination, seedling growth and seedling vigor index of kidney bean.

The germination $\%$ of kidney bean seeds, seedling length, seedling fresh and dry weights and seedling vigor index were progressively decreased with lowering temperature from 18 to $8^{\circ} \mathrm{C}$ (Fig.1 (a, b, c, d, e). Also, $5^{\circ} \mathrm{C}$ represented an extreme low temperature condition at which there was no germination and no growth. Highest germination percentage and seedling growth took place in the control plants $\left(30^{\circ} \mathrm{C}\right)$. Pretreatment of bean seeds with different levels of vitamin $\mathrm{C}$ before exposure to different temperatures pronouncedly enhanced the development of seedlings as vitamin $\mathrm{C}$ level increased.
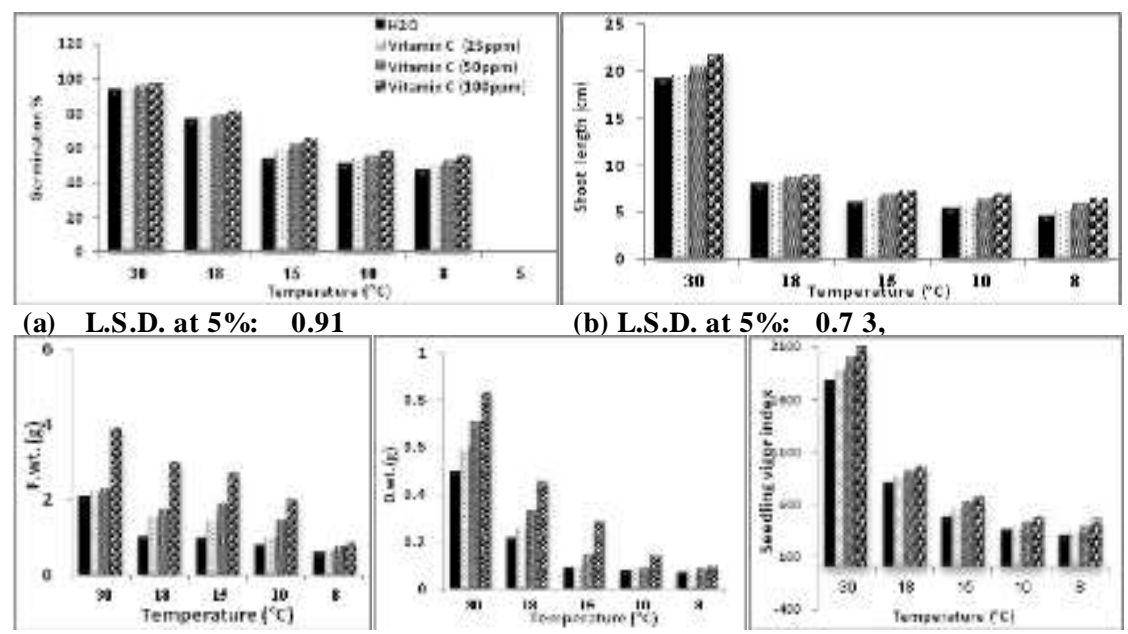

(b) L.S.D. at 5\%: 0.73 ,

(c) L.S.D. at $5 \%: 0.025$
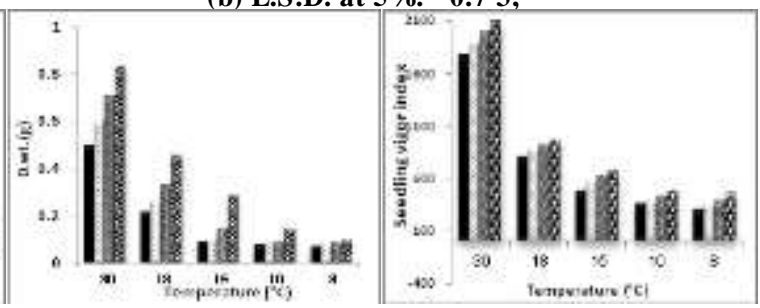

(d) L.S.D. at 5\%: 0.002

(e) L.S.D. at $5 \%: 3.8$

Fig. 1. Effect of different concentrations (ppm) of vitamin $C$ and different temperatures on: (a): germination \%;

(b): seedling length $(\mathrm{cm})$; (c,d): seedling fresh and dry weights $(\mathrm{g})$; and (e): seedling vigor index of kidney bean. Each value is the mean of 3 replicates.

Egypt. J. Bot., 56, No. 2 (2016) 
Effect of vitamin $C$ and different temperatures on total chlorophylls, total carbohydrates, soluble sugars and soluble protein contents ofkidney bean seedlings.

It is clear that the contents of total chlorophylls, total carbohydrates and total soluble proteins were significantly affected by low temperature and vitamin C pretreatments (Fig. 2 (a,b,c). Low temperatures reduced their levels in leaves, while seeds pretreated with different concentrations of vitamin $\mathrm{C}$ and subjected to low temperatures were able to produce seedlings with higher contents of the above mentioned metabolites than those without vitamin $\mathrm{C}$ pretreatments. Fig. $2 \mathrm{c}$ reveals that higher soluble sugar contents were produced by lower temperatures and vitamin $\mathrm{C}$ enhanced their accumulation, compared with untreated ones.

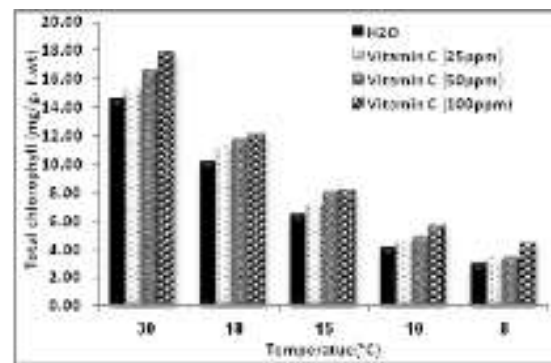

(a) L.S.D. at 5\%: 0.0034

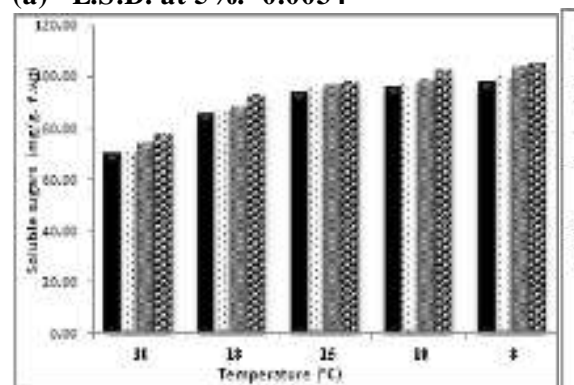

(c)

L.S.D. at $5 \%: 0.31$

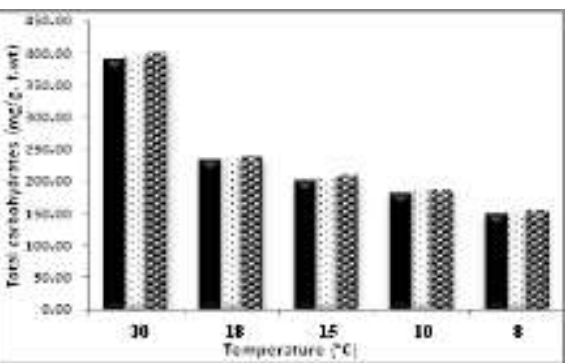

(b) L.S.D. at $5 \%: 0.79$

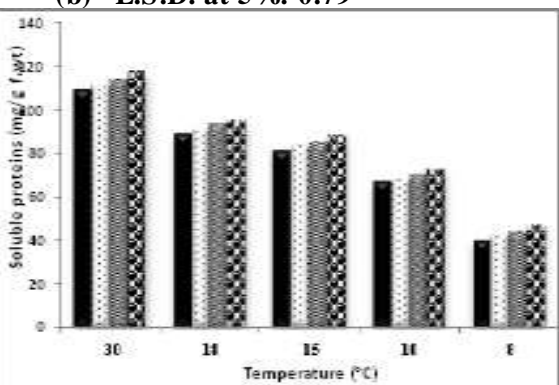

(d)

L.S.D. at $5 \%: 0.41$

Fig.2. Effect of different concentrations (ppm) of vitamin $\mathrm{C}$ and different temperatures on kidney bean seedlings content (mg/g.f.wt) of (a): total chlorophylls; (b): total carbohydrates; (c): soluble sugars; and (e): soluble proteins. Each value is the mean of 3 replicates.

Effect of vitamin $C$ and different temperatures on proline and proline dehydrogenase contents of kidney bean seedlings

Figure 3a shows that proline content of leaf tissue of bean seedlings was significantly elevated by lowering temperature level. Vitamin C pretreatments led to higher proline content of seedlings, compared with untreated ones.

Proline dehydrogenase content of kidney bean seedlings was decreased by decreasing temperature, as compared with that seedlings were not exposed to low temperatures. Vitamin $\mathrm{C}$ pretreatment caused decreases in proline dehydrogenase activities that have been induced by low temperature stress (Fig. 3b).

Egypt. J. Bot., 56, No. 2 (2016) 


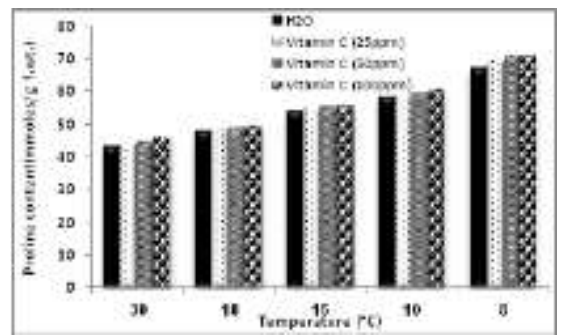

(a) L.S.D. at 5\%: 0.076

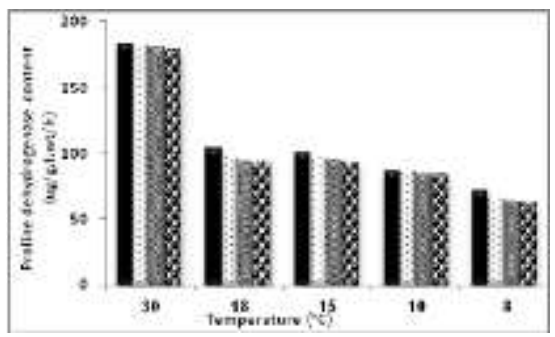

(b) L.S.D. at $5 \%: 0.61$

Fig. 3. Effect of different concentrations (ppm) of vitamin $\mathrm{C}$ and different temperatures on kidney bean seedlings content of (a): proline content (mmoles/g .f.wt.) and (b): proline dehydrogenase (ug/g.f.wt/hr). Each value is the mean of 3 replicates.

Effect of vitamin $C$ and different temperatures on amylase, protease, catalase and ascobate peroxidase enzymes content of bean seedlings.

The data presented in Fig. 4 (a,b ) indicate that the contents of the hydrolytic enzymes amylase and protease were increased by lowering temperature level. Vitamin C pretreatments also increased their levels. Concerning the antioxidant enzymes, it was found that low temperatures led to significant increases in both catalase and ascorbate peroxidase. Vitamin $\mathrm{C}$ reduced the levels induced by low temperatures (Fig. 4 (c, d).

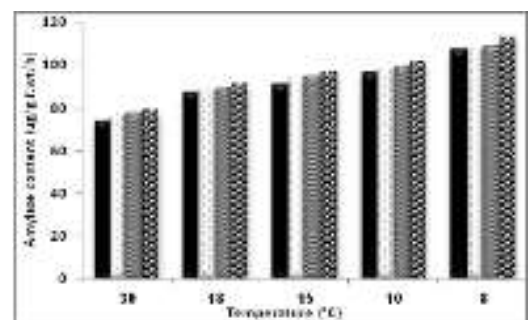

(a) L.S.D. at $5 \%: 0.37$

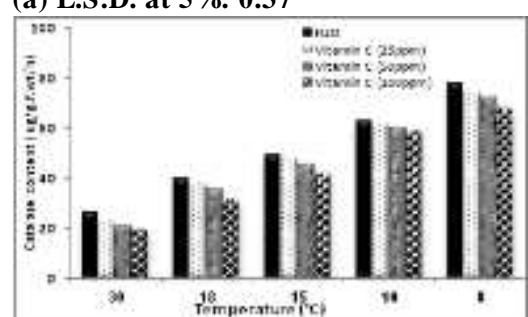

(c) L.S.D. at $5 \%: 0.38$

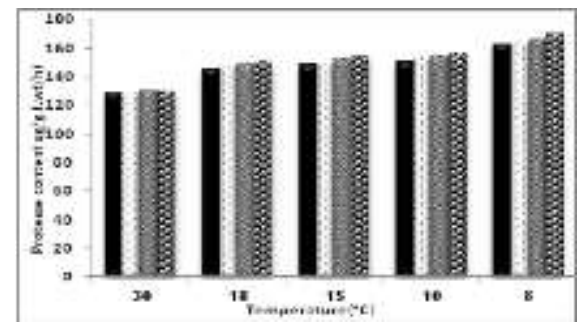

(b) L.S.D. at $5 \%: 0.45$

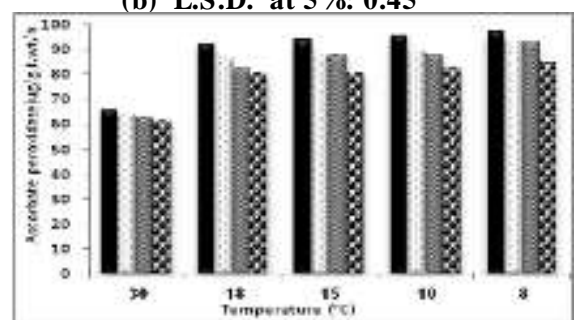

(d) L.S.D. at $5 \%: 0.27$

Fig.4. Effect of different concentrations (ppm) of vitamin $\mathrm{C}$ and different temperatures on kidney bean seedling content (ug/g.f.wt/h) of: (a): amylase; (b): protease; (c): catalase; and (d): ascorbate peroxidase. Each value is the mean of 3 replicates . 


\section{Discussion}

Seed germination, seedling growth, and metabolism of kidney bean seedlings were significantly reduced as temperature decreases. A similar trend was shown with chlorophylls (a \& b), carbohydrate and protein contents. These effects might be ascribed to an increase in reactive oxygen species that would inhibit and delay growth and development. The induced increase of soluble sugars by low temperatures could be attributed to the increased activity of the hydrolytic enzyme amylase. The accumulated soluble sugars are osmotically active substances that might share in acclimation by raising the seedling osmotic pressure and consequently, the water absorption would be increased. These results were in agreement with those of Baâtour et al. (2011). Low temperatures may lead to stomatalclosure, decrease in chlorophyll synthesis and increase in the activities of chlorophyllase, carboxylase and protease enzymes that would consequently adversely affect chlorophyll, carbohydrate and protein contents (Abd El- Aziz et al., 2006). The higher germination percentage and vigor and the enhanced contents of chlorophyll, total carbohydrates, soluble sugars and proteins by vitamin C pretreatments were in consistence with the results of Burguieres et al. (2007). Vitamin C might help seeds water absorption (Zheng et al., 2005). Vitamin C was assumed to activate and promote hydrolytic enzymes and seed antioxidant s ystem that would then lead to improve germination and growth of soybean (Lu et al., 2002). Vitamin C improved stomatal conductance, gas exchange attributes and transpiration rates of wheat genotypes (Ashraf, 2009). The amelioration of negative effects of low temperature stress by vitamin C was also pointed out by Abd El-Aziz et al. (2006). Vitamin C significantly stimulated sunflower and rape seed germination and prevented protein degradation and lipid peroxidation in germinated seeds, consequently the germination and growth rate were stimulated (Seyed, 2008). Spraying tomato plant with vitamin C caused considerable increases of promoters contents and decreases in inhibitor activities leading to hormonal balance (AbdelHalim, 1995). Vitamin C enhanced photosynthesis and growth of Vicia faba and decreased degradation of photosynthetic pigments (Hamada and Khulaef, 2000). Total carbohydrates and soluble proteins level were also significantly enhanced by vitamin C. Tomato leaves sprayed with vitamin $\mathrm{C}$ had larger stem diameter and thickness of cortical layer and palisade layer, compared with controls (Ali, 2001). Vitamin C plays important roles on photosynthesis, transmembrane electron transport and cell division control. It maintains the effectiveness of the endogenous antioxidant system that protects plants from oxidative damage due to stresses (Kun Ming et al., 2004). The functions of vitamin C are centered around the antioxidant properties (Mark et al., 2005). Vitamin C can neutralize free radicals which are disturbing-causing agents (Olmos et al., 2006). Vitamin C functions as a major redox buffer and as a cofactor for enzymes involved in regulating photosynthesis, hormone biosynthesis and regenerating other antioxidants. It also involves in signal transduction (Daniel, 2013).

According to the results, the significant increase in proline content by low temperatures might be ascribed to the increased synthesis of proline which 
is a common metabolic reaction to plants under stress and to some extent may be attributed to the deficit of proline dehydrogenase; the enzyme catalyzing proline conversion into glutamic acid under normal conditions. These results are in agreement with those of Misra and Gupta (2005) who reported that proline acted as an osmotic regulator and antioxidant substrate that was elevated under stresses as an attempt to mitigate low temperature stress. The slight increase in proline level by vitamin $\mathrm{C}$ pretreatments and the decrease in proline dehydrogenase activity induced by low temperatures were in agreement with the conclusion of Jain et al. (2001).

According to the results obtained in the present work, the decreased contents of carbohydrates and proteins under low temperatures might be accredited to the remarkable activity of amylase and protease enzymes which are hydrolytic enzymes significantly increased under low temperature for adequate supplying of soluble sugars and amino acids needed for germination and growth. This agrees with the results of Vandana et al. (2015). Vitamin C gradually increased their activity for satisfying the required demands of sugars and amino acids under stress conditions. The decreased carbohydrate levels under low temperature conditions may be attributed to the depressed photosynthetic rate in leaves (Farrar, 1988). Increased catalase and ascorbate peroxidase activities under low temperatures might impair tolerance to low temperatures oxidative stress. The effect of vitamin $C$ pretreatment on catalase activity, in the present study, agrees with the result of Seyed (2008). The present results also agree with those of Maittler et al. (2004). Although the formation of reactive oxygen species occurs naturally as a by-product of metabolism, environmental stresses are known to increase ROS to toxic levels resulting in severe damage to cellular structures and cell death (Sharma et al., 2012).

According to our results the higher tolerance of low temperatures was found to be correlated with higher contents of antioxidant defensive enzymes under low temperatures stress. Demiral and Turkan (2005) reported that antioxidant enzymes enable plants to maintain growth under stress conditions. Thus, vitamin $\mathrm{C}$ pretreatment of kidney bean seeds had a cumulative protection effect from mild low temperatures.

\section{References}

Abd El Aziz, G, N., Azza, A., Mazher, A.M., and El-Habba, E. (2006) Effect of foliar spray with ascorbic acid on growth and chemical constituents of Khaya senegalensis grown under salt conditions. American Eurasian. J. Agric \& Environ. Sci., 1, 207-214.

Abdel-Halim, S.M. (1995) Effect of some vitamins as growth regulators on growth, yield and endogenous hormones of tomato plants during winter. Egypt. J. App. Sci., 10 (12), 322-334. 
Alexander S., Lukatkini, A., Brazaitiyte, S., Bobinas, P. and Duchovskis, S. (2012) Chilling injury in chilling-sensitive plants: a review, Žemdirbyst Agriculture. 99, 2: $111-124$.

Ali, Z.A. (2001) Ascorbic acid induced anatomical changes in leaves and stems of tomato plants. Bull. Nat. Res. Centre, Cairo. 26 (3), 371-382.

Ashraf, M. (2009) Biotechnological approach of improving plant salt tolerance using antioxidants as markers. Biotech. Adv., 27, 84-93.

Baâtour, O., Kaddour, R., Mahmoudi, H., Tarchoun, I., Bettaieb, I., Nasri, N. Mrah, S., Hamdaoui, G., Lachaâl, M. and Marzouk, B. (2011) Salt effects on Origanum majorana fatty acid and essential oil composition. J. Sci. Food Agric., 91(14), 2613-20.

Bates, L.S., Waldren, R.P. and Teare. I.D. (1973) Rapid determination of free proline for water stress studies. Plant Soil, 39, 205-207.

Behairy, R. T., Mohamed, E. and Lyle, C. (2012) Impact of ascorbic acid on seed germination, seedling growth, and enzyme activity of salt-stressed Fenugreek. J. Med. Active Plants., 1(3),106-113.

Bergmeyer, H.U. (1974) "Method of Enzymatic Analysis". Velage Chemic, Winheim, Academic Press, New York.

Bradford, M.M. (1976) A rapid and sensitive method for the quantitation of microgram quantities of protein utilizing the principle of protein dye binding. Analytical Biochem., 72 248-254.

Burguieres, E., McCue, P., Kwon, Y.I. and Shetty, K. (2007) Effect of vitamin C and folic acid on seed vigor response and phenolic-linked antioxidant activity. Bioresour Technol., 98 (7), 1393-404.

Carter, C.T., Brown, L.S. and Ungar, A.I. (2003) Effect of temperature regimes on germination of dimorphic seeds of Atriplex rostrate. Biol Plant, 47(2), 269-272.

Daniel R. G. (2013) L-Ascorbic Acid: "A Multifunctional Molecule Supporting Plant Growth and Development”. Scientifica. Article ID 795964, 24 pages.

Demiral, T. and Turkan, I. (2005) Comparative lipid peroxidation, antioxidant defense systems and proline content in roots of two rice cultivars differing in salt tolerance. Environ. Exp. Bot., 53, 247-257.

Dogras, C.C., Dilley, D.R. and Farrar, J.F. (1988) Temperature and the partitioning and translocation of carbon. In: "Plants and Temperature". Long SP, Woodward FI, Eds. Cambridge: The Company of Biologists Limited, pp. 203-235.

Hamada, A.M. and Khulaef, E.M. (2000) Stimulative effects of ascorbic acid, thiamine or pyridoxine on Vicia faba growth and some related metabolic activities. Pakistan J. Biol. Sci., 3, 1330-1332.

Egypt. J. Bot., 56, No. 2 (2016) 
IS TA Rules (1999) International rules for seed testing. Seed Science \& Technol. Proc. Int. Seed Test. Assoc, 31(1),1-152.

Jain, M., Mathur, G., Koul, S. and Sairin, N. B. (2001) Ameliorative effects of proline on salt stress- induced lipid peroixdation in cell lines of groundnut. Plant Cell Rep., 20, 463-468.

Kang, H.M. and Saltveit, M.E. (2001) Activity of enzymatic antioxidant defense systems in chilled and heat shocked cucumber seedlings radicles. Physiol Plant., 113, $548-556$.

Kun Ming, C., Hai Jun, G. and Suo Min, W. (2004) Biosynthesis, transport and function of ascorbate in plants. Acta Botanica Boreali Occidentalia Sinica., 24 (2), 329-336.

Kurt, O. (2010) “Tarla Bitkileri Yetitirme Teknii”. Ondokuz Mays Üniversitesi, Ziraat Fakültesi Yaynlar No:44.

Lowry, O. H., Rosen, J., Fan, A. C. and Randel, R. J. (1951) Protein measurement with folin phenol reagent. J. Biol.Chem., 193, 265- 275.

Lu, C.M., Zhang, C.Y., Wen, J.Q., Wa, G.R. and Tao, M.X. (2002) Research of the effect of nanometer materials on germination and growth enhancement of glycine max and its mechanism. Soybean Sci., 21, 168-172.

Mark, W., Marc, V.M., Dirk, I., Maite, S., Angelos, K. and John, F. (2005) Plant Lascorbic acid: chemistry, function, metabolism, bioavailability and effects of processing physiol., 139, 1291-1303.

Metzner, H., Rau, H. and Senger, H. (1965) Unter suchungen zur synchrnisier barteit einzelner pigmentation angel mutanten von Chlorella. Planta, 65, 186.

Misra, N. and Gupta. A.K. (2005) Effect of salt stress on proline metabolism in two high yielding genotypes of green gram. Plant Sci., 169, 331-339.

Mittler, R., Vanderauwera, S., Gollery, M. and Van Breusegem, F. (2004) Reactive oxy gen gene network of plants. Trends in Plant Sci., 9(10), 490-498.

Olmos, E., Kiddle, G., Pellny, T. K., Kumar, S. and Foyer, C. H. (2006) Modulation of plant morphology, root architecture, and cell structure by low vitamin $\mathrm{C}$ in Arabidopsis thaliana. J. Exp. Bot., 57 (8),1645-1655.

Raison, J.K. and Lyons, J.M. (1986) Chilling injury: a plea for uniform terminology . Plant Cell Environ., 10.1111/ j.1365-3040.

Raven, E. (2000) Peroxidase-catalyzed oxidation of ascorbate. Structural, spectroscopic and mechanistic correlations in ascorbate peroxidase. Subcell Biochem., 35, 317-49.

Egypt. J. Bot., 56, No. 2 (2016) 
Seyed, A.M. (2008) Effect of ascorbic acid, pyridoxine and hy drogen peroxide treatments on germination, catalase activity, protein and malondialdehyde content of three oil seeds. Notulae Botanicae Horti Agrobotanici Cluj-Napoca., 36(2), 61-66.

Sharma, P., Jha, A.B., Dubey, R.S. and Pessaaki, M. (2012) Reactive oxy gen species, oxidative damage, and antioxidative defense mechanism in plants under stressful conditions.. J. Bot., (ID217037) : 26.

Shalata, A. and Neumann, P. M. (2001) Exogenous ascorbic acid increases resistance to salt stress and reduces lipid peroxidation. J. Exp. Bot., 52, 2207-2211.

Suthar, C., Naik, V.R and Mulani, R.M. (2009) Seed and seed germination in Solanum nigrum Linn. American-Eurasian J. Agric. Envir. Sci., 5 (2),179-183.

The Real seed catalogue: “The Best Vegetable Seeds for the Kitchen Garden”, UK Ltd Company No. 5924934, DEFRA Registered Seed Merchant No 7289.

Tzortzakis, N.G. (2009) Effect of pre-sowing treatment on seed germination and seedling vigor in endive and chicory. Hort Sci . (Prag ue). 36(3), 117-125.

Umbriet, W.W., Burris, R.H., Stauffer, J.F., Cohen, P.P., Johanse, W.J., Lee Page, G.A., Potter,V. R and Schneided, W.C. (1959) "Monometric Technique: A manual description method applicable to study of describing metabolism. P: 239. Burgess Publishing Company.

Zeinolabedin, J. R. and Saeed, S. (2013) Chilling stress in plants. Int. J. Agric. Crop Sci., IJACS; 5 -24, 2961-2968.

Zheng, L., Hong, F., Lu, S. and Liu, C. (2005) Effect of nano-TiO2 on strength of naturally aged seeds and growth of spinach. Biol Trace Elem Res.,105, 83-91.

(Received 29/10/2015; accepted 24/ 2 /2016) 


\title{
تاثير فيتامين ج على إنبات ونمو البادرات وبعض الأنشطة الأيضية

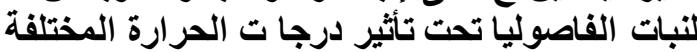

حنان محمد أبو الغيط قسم النبات و الميكروبيولوجى أفيطى ـ كلبة العلوم- جامعة حلوانـ القاهرة- مصر.

\begin{abstract}
استهاف هذا البحث دراسة تأثير درجات الحرارة المختلفة والمعالجة المسبقة

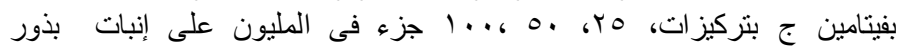

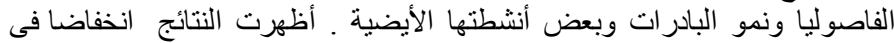

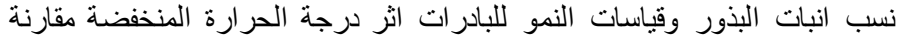

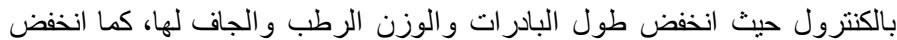

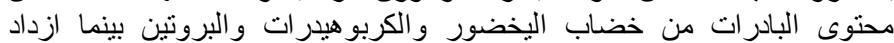

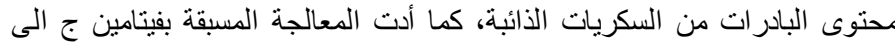

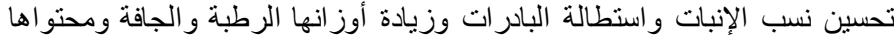

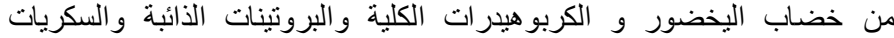

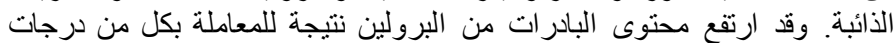

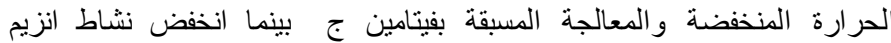

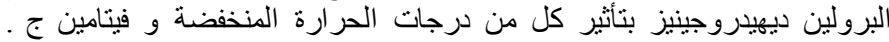

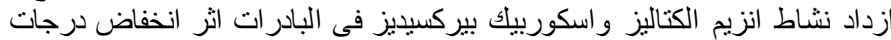

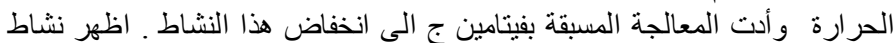

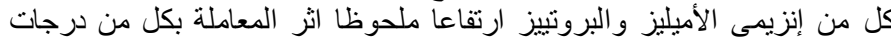

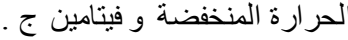

